\title{
Dipeptide (Tyr-lle) Acting as an Inhibitor of Angiotensin -I-Converting Enzyme (ACE) from the Hydrolysate of Jellyfish Nemopilema nomurai
}

\author{
Yeon-Kye Kim, Chi-Won Lim*, So-mi Yeun, Moon-Hee Lee, Ho-Sung Moon, Hyeon-Ah Cho, Na-Young \\ Yoon, Ho-Dong Yoon, Hee-Yeon Park and Doo-Seog Lee \\ Food and Safety Research Division, National Fisheries R\&D Institute, Busan 619-705, Korea
}

\begin{abstract}
The jellyfish Nemopilema nomurai was hydrolyzed with papain and a novel dipeptide purified via ultrafiltration, gel filtration chromatography with Sephadex LH-20, and reverse phase chromatography using $\mathrm{C}_{18}$ and $\mathrm{C}_{12}$ columns. The IR, $1 \mathrm{H} \mathrm{NMR,} \mathrm{13C} \mathrm{NMR,}$ and MS spectrometer analyses showed that the dipeptide comprised tyrosine-isoleucine (Tyr-Ile). The IC $\mathrm{In}_{50}$ and $K_{\mathrm{i}}$ values were 6.56 \pm 1.12 and $3.10 \pm 0.28 \mu \mathrm{M}$, respectively, indicating competitive inhibition of angiotensin-I-converting enzyme (ACE). As a novel ACE-inhibitory active peptide, Tyr-Ile may have potential for use in antihypertensive therapy.
\end{abstract}

Key words: ACE, Jellyfish, Nemopilema nomurai, Papain, Tyrosine-isoleucine

\section{Introduction}

Functional foods may contain bioactive peptides since they exert a physiological effect in the body. These peptides are released from dietary protein by enzymatic hydrolysis or during processing. Bioactive peptides that regulate blood pressure are believed to be inhibitors of angiotensin-I-converting enzyme (ACE). Those peptides are, in general, inactive within the sequence of the parent protein, but can be released during gastrointestinal digestion or food processing (Shahidi and Zhong, 2008). Recently, many ACE-inhibitory peptides have been isolated and characterized from various protein hydrolysates such as cheese (Smacchi and Gobbetti, 1998), milk protein (Gobbetti et al., 2000), egg white (Miguel et al., 2007), plant protein (Dziuba et al., 1999; Wu et al., 2008), meat (Jang and Lee, 2005), and marine resources (Je et al., 2005; He et al., 2006). Various ACE-inhibitory peptides have also been isolated from fish protein, e.g., sardines (Matsui et al., 1993), tuna (Kohama et al., 1988), and cod (Kim et al., 2000). Protein hydrolysates are usually produced by gastrointestinal en- zymes (e.g., pepsin or pancreatin) or microbial enzymes (e.g., Protamex; Novozymes, Bagsvaerd, Denmark) under varying conditions.

ACE (EC 3.4.15.1) is a circulating enzyme that participates in the rennin-angiotensin system and plays an important physiological role in regulating blood pressure. ACE acts as an exopeptidase that cleaves dipeptides from the $\mathrm{C}$-terminus of various oligopeptides. It converts the inactive form of decapeptide (angiotensin I) to a potent octapeptide vasoconstrictor (angiotensin II), and inactivates the catalytic function of bradykinin, which has a depressor action (Ondetii et al., 1977; FitzGerald et al., 2004).

Nemopilema nomurai is a giant jellyfish species that has been blooming offshore of Korea, China, and Japan in the last several years. Jellyfish have traditionally been consumed to treat asthma and hypertension in East Asian countries. Despite this, knowledge of the active compound(s) is lacking. Thus, the aim of this study was to determine the functional prop-
Open Access http://dx.doi.org/10.5657/FAS.2011.0283

This is an Open Access article distributed under the terms of the Creative Commons Attribution Non-Commercial License (http://creativecommons. org/licenses/by-nc/3.0/) which permits unrestricted non-commercial use, distribution, and reproduction in any medium, provided the original work is properly cited. pISSN: 2234-1749 eISSN: 2234-1757
Received 6 October 2011; $\quad$ Revised 1 November 2011; Accepted 8 November 2011

*Corresponding Author

E-mail: E-mail: cwlim@nfrdi.go.kr 
erties of the active compounds of $N$. nomurai and assess its possible application in antihypertensive therapy. We hydrolyzed $N$. nomurai jellyfish with papain, and then purified and elucidated the structure and the inhibition pattern of an ACEinhibitory peptide.

\section{Materials and Methods}

\section{Materials}

A giant jellyfish, N. nomurai, was caught south of Jeju Island, Korea. Only the umbrella (mesogloea) was collected, washed with deionized water, and then stored at $-23^{\circ} \mathrm{C}$ until required. ACE from rabbit lung, the substrate hipuryl-L-histidyl-L-leucine (Hip-His-Leu), trifluoroacetic acid (TFA), acetonitrile $\left(\mathrm{CH}_{3} \mathrm{CN}\right)$, and papain were purchased from Sigma-Aldrich Chemical Co. (St. Louis, MO, USA). Sephadex LH-20 (Amersham Pharmacia Biotech, Tokyo, Japan) used for gel filtration chromatography, and $\mathrm{C}_{18}$ and $\mathrm{C}_{12}$ columns used for reverse-phase HPLC were obtained from Phenomenex Inc. (Torrance, CA, USA). Other reagents were of reagent grade and used without further purification.

\section{Enzymatic hydrolysis}

Papain hydrolysis of the jellyfish was conducted under the following conditions. First, jellyfish samples were lyophilized to remove excess water. Enzymatic hydrolysis $(100 \mathrm{~mL})$ was carried out for $4 \mathrm{~h}$ with $10 \%(\mathrm{w} / \mathrm{v})$ lyophilized jellyfish at $60^{\circ} \mathrm{C}$ and $\mathrm{pH}$ 6.0. The ratio of enzyme to reaction volume was varied from 0 to $2 \%(\mathrm{w} / \mathrm{v})$. Each enzyme reaction was stopped by heat treatment at $90^{\circ} \mathrm{C}$ for $15 \mathrm{~min}$. The resultant slurry was centrifuged at 3,000 $\mathrm{g}$ for $10 \mathrm{~min}$, and the supernatant was lyophilized and then used for analysis. The degree of hydrolysis was defined as the proportion (\%) of $\alpha$-amino nitrogen with respect to the total-N in the samples (Taylor, 1957).

$$
\text { Degree of hydrolysis }(\%)=\left(\mathrm{h} / \mathrm{h}_{\mathrm{tot}}\right) \times 100 \text {, }
$$

where $\mathrm{h}_{\text {tot }}$ is the total- $\mathrm{N}$ of lyophilized samples, and $\mathrm{h}$ is the quantity of $\alpha$-amino nitrogen.

\section{Determination of ACE-inhibitory activity}

ACE-inhibitory activity was determined using the modified method of Cushman and Cheung (1971). The standard reaction mixture contained $5 \mathrm{mM}$ Hip-His-Leu as a substrate, 0.3 $\mathrm{M} \mathrm{NaCl}$, and $5 \mathrm{mU} \mathrm{ACE}$ in $50 \mathrm{mM}$ sodium borate buffer $(\mathrm{pH}$ 8.3). A sample $(50 \mu \mathrm{L})$ was added to enzyme solution $(50 \mu \mathrm{L})$ and then mixed with $8.3 \mathrm{mM}$ Hip-His-Leu $(150 \mu \mathrm{L})$ containing $0.5 \mathrm{M} \mathrm{NaCl}$ to obtain the same concentration as the standard reaction mixture. After incubation at $37^{\circ} \mathrm{C}$ for $30 \mathrm{~min}$, the reaction was stopped by the addition of $1.0 \mathrm{~N} \mathrm{HCl}(250 \mu \mathrm{L})$.
The resulting hippuric acid was extracted by addition of 1.5 $\mathrm{mL}$ ethyl acetate. After centrifugation $(800 \mathrm{~g}, 15 \mathrm{~min}), 1 \mathrm{~mL}$ of the upper layer was transferred to a new glass tube and evaporated at room temperature for $2 \mathrm{~h}$ in a vacuum. The extracted hippuric acid was dissolved in $3.0 \mathrm{~mL}$ distilled water, and the absorbance at $228 \mathrm{~nm}$ was measured using a spectrophotometer (model U-3210; Hitachi Co., Tokyo, Japan).

\section{Fractionation of jellyfish hydrolysates}

The papain hydrolysate showing the greatest inhibitory activity was selected and the resultant hydrolysate was fractionated through an Amicon Millipore membrane (1 kDa cutoffs; Amicon, Beverly, MA, USA). The resultant fraction (FII) was lyophilized and then stored at $-82^{\circ} \mathrm{C}$ until required.

\section{Purification of ACE-inhibitory peptide}

The active fraction (FII) was further purified by Sephadex LH-20 $(25 \times 250 \mathrm{~mm})$ gel filtration chromatography, eluting with $30 \%$ methanol at a flow rate of $0.5 \mathrm{~mL} / \mathrm{min}$, and reversephase HPLC eluting with a linear gradient of $\mathrm{MeOH}-\mathrm{H}_{2} \mathrm{O}$ (A eluent; $\mathrm{H}_{2} \mathrm{O}: \mathrm{MeOH}: \mathrm{TFA}=90: 10: 0.1(\mathrm{v} / \mathrm{v} / \mathrm{v})$, B eluent; $\mathrm{MeOH}: \mathrm{H}_{2} \mathrm{O}:$ TFA $\left.=90: 10: 0.1(\mathrm{v} / \mathrm{v} / \mathrm{v})\right)$ at a flow rate of $2 \mathrm{~mL} /$ $\min \left(\mathrm{C}_{18} 5 \mu \mathrm{M}\right.$ ODS $3100 \mathrm{~A}, 10 \times 250 \mathrm{~mm}$, UV detection at $214 \mathrm{~nm}$; Phenomenex). To obtain pure peptide, a Jupiter Proteo $\mathrm{C}_{12}$ column (90 $\AA, 10 \mu \mathrm{m}, 21.2 \times 150 \mathrm{~mm}$; Phenomenex) was used at a flow rate of $2 \mathrm{~mL} / \mathrm{min}$ with a linear $\mathrm{CH}_{3} \mathrm{CN}-\mathrm{H}_{2} \mathrm{O}$ gradient (A eluent; $\mathrm{H}_{2} \mathrm{O}: \mathrm{CH}_{3} \mathrm{CN}: \mathrm{TFA}=95: 5: 0.1(\mathrm{v} / \mathrm{v} / \mathrm{v}), \mathrm{B}$ eluent; $\mathrm{CH}_{3} \mathrm{CN}: \mathrm{H}_{2} \mathrm{O}:$ TFA $=$ 55:45:0.08 (v/v/v).

\section{Structure of the purified peptide}

The IR spectra were recorded on a Fourier transform (FT)IR model IFS-88 spectrometer (Bruker, Billerica, MA, USA). NMR spectra were recorded on a JEOL JNM ECP-400 (400 $\mathrm{MHz}$ for $1 \mathrm{H}, 100 \mathrm{MHz}$ for $13 \mathrm{C}$ ) spectrometer (JEOL Ltd., Tokyo, Japan). Chemical shift $(\delta)$ values were expressed in ppm and were referenced to the residual solvent signals with resonances at $\delta \mathrm{H} / \delta \mathrm{C}, 7.26 / 77.0\left(\mathrm{CDCl}_{3}\right)$. To calculate molecular weights, purified samples were processed on an $1100 \mathrm{LC} /$ MSD spectrometer (Agilent Technologies, Santa Clara, CA, USA) with direct injection onto an electrospray interface in the positive or negative mode. The structure of the purified peptide was conformed using Chemdraw 11 (CambridgeSoft, Cambridge, MA, USA).

\section{$I_{50}$ values and kinetic analysis}

The $\mathrm{IC}_{50}$ value of the purified peptide was determined by a standard method, and was defined as the concentration of inhibitor required to inhibit $50 \%$ of ACE activity. For a Lineweaver-Burk plot, $0-4 \mu \mathrm{g} / \mathrm{mL}$ of purified peptide was added to the reaction solution as an inhibitor, and the inhibition pattern 
and $K_{\mathrm{i}}$ were estimated using GraFit 5.0 (GraFit Software, Surrey, UK).

\section{Results and Discussion}

\section{Papain digestion of jellyfish}

The hydrolysis rates of jellyfish mesogloea ranged from 2 to $17 \%$, depending on the papain concentration used. Examination of the ACE-inhibitory activity of each hydrolysate revealed that the activity increased significantly by as much as $62 \%$ after $4 \mathrm{~h}$ digestion, although negligible activity was detected in intact jellyfish. The greatest inhibitory activity was obtained with an enzyme concentration of $0.2 \%(\mathrm{w} / \mathrm{v})$, and it then leveled off even in a prolonged reaction (Fig. 1). Papain can digest most protein substrates and exhibits a broad substrate specificity, cleaving the peptide bonds of basic amino acids, leucine, or glycine. Because of this broad substrate specificity, many peptides and amino acids have been produced, leading to higher ACE-inhibitory activity. Lee et al. (2001) and Kim et al. (1996) reported that no relationship existed between the degree of hydrolysis of laver and freshwater fish and ACE-inhibitory activity. In the case of laver hydrolysate, both neutrase and papain achieved a similar degree of hydrolysis $(50.7 \%$ and $51.3 \%$, respectively) and ACEinhibitory activity ( $34.3 \%$ and $34.9 \%$, respectively), whereas the hydrolysis rate and ACE-inhibitory activity of jellyfish differed markedly. This indicates that different substrates will show clear differences in reaction pattern.

\section{Fractionation and characterization of papain hydrolysate}

The papain hydrolysate was fractionated by ultrafiltration ( $1 \mathrm{kDa} \mathrm{MWCO}$ ) and the activity determined. The resulting fraction (FII, $<1 \mathrm{kDa}$ ) possessed $61.1 \%$ of the total activity, whereas the retained fraction (FI, $>1 \mathrm{kDa}$ ) possessed $35.0 \%$ (Fig. 2). These findings suggested that the most active compounds were present in the FII fraction and that this activity was newly exposed by papain treatment because no recognizable inhibitory activity was detected before papain hydrolysis. Molecular weights (Mw) of fraction FII were less than $1 \mathrm{kDa}$, since a $1 \mathrm{kDa}$ MWCO membrane was used.

To inhibit ACE in vivo, peptides must reach the blood intact. Many barriers in the body might limit or enhance the activity of the peptides in vivo. When proteins or peptides are ingested, the first barriers are the stomach and small intestine, where proteins and peptides are broken down by enzymes such as pepsin, trypsin, and $\alpha$-chymotrypsin. The resulting oligopeptides and free amino acids are absorbed into the blood. During absorption, peptides are further hydrolyzed by brush border peptidases and peptidases in enterocytes (Vermeirssen et al., 2004). Byun and Kim (2001) observed a correlation between

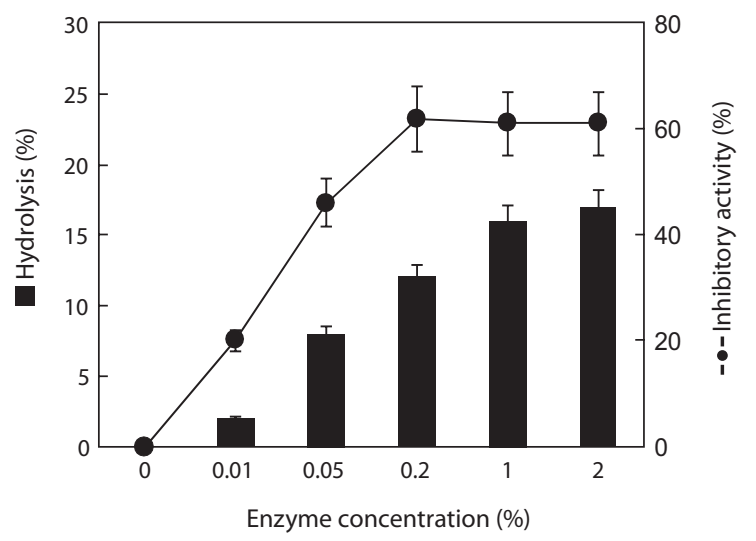

Fig. 1. Degree of hydrolysis and angiotensin-l-converting enzyme (ACE)-inhibitory activity of jellyfish hydrolysate. Papain was used to hydrolyze Nemopilema nomurai and the inhibitory activity of the resulting hydrolysate was determined by the method mentioned in Materials and Methods. —, hydrolysis (\%); -•-, ACE inhibition (\%).

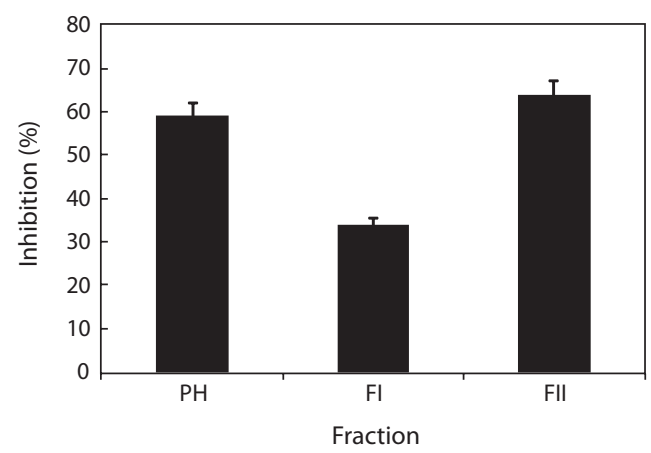

Fig. 2. Angiotensin-l-converting enzyme (ACE)-inhibitory activity of the fractionated jellyfish hydrolysate. The resultant hydrolysate was fractionated using amicon millipore membrane filters ( $1 \mathrm{kDa}$ cut offs), then the inhibitory activity was determined by the standard method. PH, papain hydrolysate before fractionation; $\mathrm{Fl},>1 \mathrm{kDa}$; $\mathrm{Fll},<1 \mathrm{kDa}$.

the molecular weight of hydrolysate and the specificity of the ACE-inhibitory activity, and revealed that activities increased with decreasing molecular weight. However, we were unable to detect a correlation between molecular weight and ACEinhibitory activity.

\section{Purification of the ACE-inhibitory peptide}

To purify the ACE-inhibitory peptide, fraction FII was subjected to a Sephadex LH-20 column, and two major fractions were obtained: FII-A and FII-B (Fig. 3). The ACE-inhibitory activities of FII-A and FII-B represented 54.01\% and 55.08\%, respectively. FII-B was further purified by HPLC using a reverse-phase column (ODS $\mathrm{C}_{18}$ ). Inhibitory activity was detected in a wide range of eluted fractions (FII-B(I)-FII-B(VII)), indicating that many inhibitory peptides were exposed by papain treatment. For further purification, FII-B(IV), which 


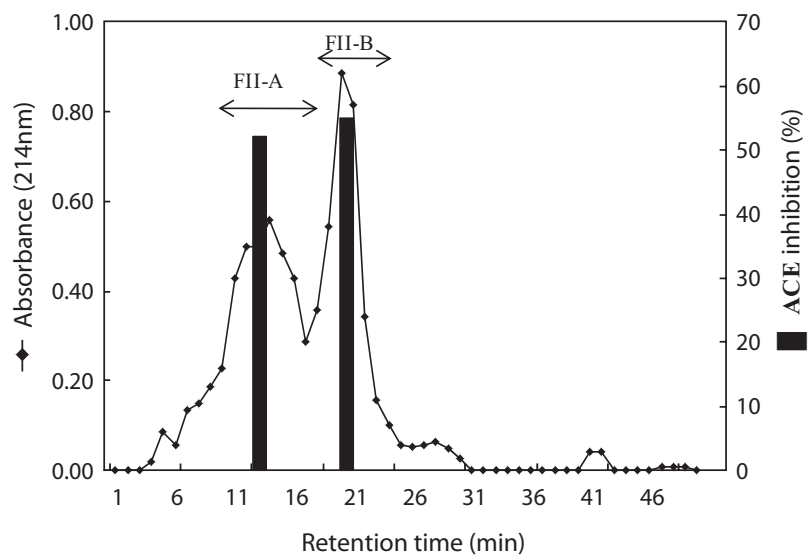

Fig. 3. Gel filtration chromatography of the fraction Fll on Sephadex LH-20. Separation was performed with $30 \%$ aqueous methanol solution at a flow rate of $0.5 \mathrm{~mL} / \mathrm{min}$ and collected with fraction volume of $5 \mathrm{~mL}$. The fraction corresponding to FII-B was collected and determined the inhibitory activities. $\rightarrow$, Absorbance at $214 \mathrm{~nm}$; $\mathbf{\square}$, ACE inhibition (\%).

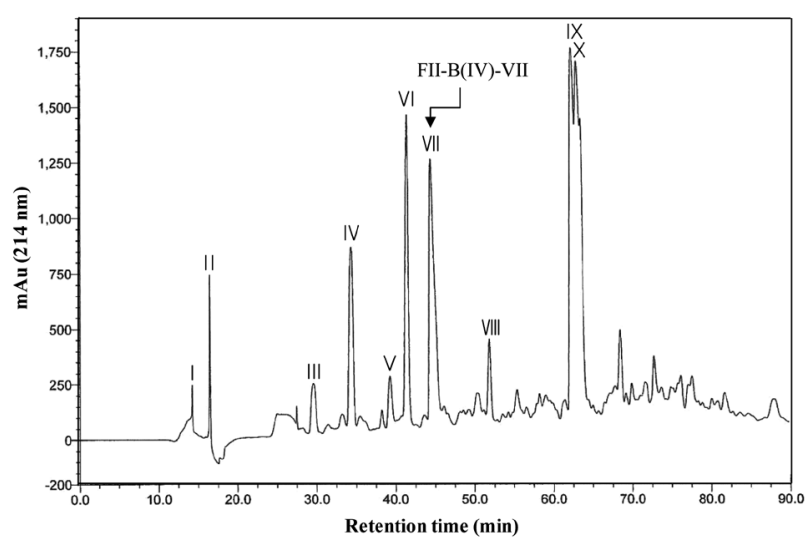

Fig. 4. Separation chromatogram of the FII-B(IV) by using $C_{12}$ reversephase column. The resultant active fraction (FII-B(IV)) after $C_{18}$ column chromatography was loaded on a Jupiter Proteo $C_{12}$ column $(90 \AA \AA, 10 \mu \mathrm{m}$, $21.2 \times 150 \mathrm{~mm}$ ) and eluted with a linear gradient of $\mathrm{CH}_{3} \mathrm{CN}_{-} \mathrm{H}_{2} \mathrm{O}$ [A eluent; $\mathrm{H}_{2} \mathrm{O}: \mathrm{CH}_{3} \mathrm{CN}: \mathrm{TFA}=95: 5: 0.1(\mathrm{v} / \mathrm{v} / \mathrm{v})$, B eluent; $\mathrm{CH}_{3} \mathrm{CN}_{2} \mathrm{H}_{2} \mathrm{O}: \mathrm{TFA}=$ 55:45:0.08 $(\mathrm{v} / \mathrm{v} / \mathrm{v})]$ at a flow rate of $2 \mathrm{~mL} / \mathrm{min}$. The inhibitory activity of each elute from I to $\mathrm{X}$ was determined and the resultant active fraction, FII-B(IV)-VII was obtained.

Table 1. ACE-inhibitory activity and purification yield of each step

\begin{tabular}{lcc}
\hline Fraction & $\mathbf{I C}_{\mathbf{5 0}}(\boldsymbol{\mu g} / \mathbf{m L})$ & Purification yield (\%) \\
\hline PH & $12.0 \pm 1.21\left(\times 10^{3}\right)$ & 100 \\
FII & $1.90 \pm 0.27\left(\times 10^{3}\right)$ & $9.40 \pm 1.71$ \\
FII-B & $0.20 \pm 0.03\left(\times 10^{3}\right)$ & $2.01 \pm 0.27$ \\
FII-B(IV) & $12.01 \pm 0.91$ & $0.51 \pm 0.08$ \\
FII-B(IV)-VII & $1.93 \pm 0.33^{*}$ & $0.08 \pm 0.02$
\end{tabular}

The fraction was obtained after each separation step. Purification yield (\%) was calculated with the amount of total- $\mathrm{N}$ obtained. Values were expressed as mean $\pm \mathrm{SD}$. ACE, angiotensin-l-converting enzyme; $\mathrm{PH}$, Papain hydrolysate; FIl, ultrafiltrate $(<1 \mathrm{kDa})$; FII-B, Sephadex LH-20; FII-BIV, ODS $\mathrm{C}_{18}$; FII-BIV-VII, ODS C 12 . "Based on the molecular weight (294.16 Da) of FII$\mathrm{B}(\mathrm{IV})-\mathrm{VII}$, the $\mathrm{IC}_{50}$ value was calculated to be $6.56 \pm 1.12 \mu \mathrm{M}$. exhibited the highest ACE-inhibitory activity, was applied to another reverse-phase column (ODS $\mathrm{C}_{12}$ ), and a pure active peptide, FII-B(IV)-VII, was obtained (Fig. 4). The purification yield and $\mathrm{IC}_{50}$ value of $\mathrm{FII}-\mathrm{B}(\mathrm{IV})$-VII were $0.08 \pm 0.02 \%$ and $1.93 \pm 0.33 \mu \mathrm{g} / \mathrm{mL}$, respectively (Table 1). Based on the molecular weight (294.16 Da) determined by an Agilent 1100 $\mathrm{LC} / \mathrm{MSD}$ spectrometer, the $\mathrm{IC}_{50}$ value was $6.56 \pm 1.12 \mu \mathrm{M}$.

Lee et al. (2005) purified ACE-inhibitory peptides from goat's milk casein hydrolysates of pepsin, and showed their sequences to be Ala-Tyr-Phe-Tye and Pro-Tyr-Tyr. Gao et al. (2010) also produced ACE-inhibitory peptides from papaindigested cottonseed hydrolysate, and calculated the $\mathrm{IC}_{50}$ values to range from 0.159 to $0.792 \mathrm{mg} / \mathrm{mL}$, even though they did not elucidate the structure.

In this work, we hydrolyzed jellyfish with papain and purified an ACE-inhibitory peptide (FII-B(IV)-VII) from the hydrolysate. These findings led us to postulate that many proteolytic enzymes, including papain, may be applied to produce ACE-inhibitory peptides of varying molecular weights from several jellyfish species.

\section{Structure of the purified peptide}

To elucidate the structure of FII-B(IV)-VII, several techniques were employed. The IR spectrum showed an NH/OH vibrational frequency at $3,398 \mathrm{~cm}^{-1}$ and peptide bond amine peak $(\mathrm{CN})$ at $1,203 \mathrm{~cm}^{-1}$, whereas the carbonyl and broad peaks of the cyclic ring appeared at 1,672 and $1,468 \mathrm{~cm}^{-1}$, respectively. These IR data indicated that the peptide contains a phenolic ring.

The 1H, 13C NMR, and DEPT data allowed assignment of seven methine, two methylene, and two methyl groups. The remaining quaternary centers consisted of a carbonyl (172.4 ppm), hydroxyl (155.2 ppm), and double-bonded (163.3 ppm) oxygenated carbon signals. The $1 \mathrm{H}$ NMR spectrum showed that the peaks at $\delta 1.14,1.32,2.95$, and 3.08 ppm were related to the methylene protons of the ester group (Table 2). These data convinced us that FII-B(IV)-VII contains tyrosine and isoleucine. The methine protons of isoleucine appeared at $\delta$ 1.87 and $3.73 \mathrm{ppm}$, and those of tyrosine appeared at $\delta 3.97$ ppm. The methine protons attached to the cyclic side chain appeared at $\delta 6.71$ and $7.01 \mathrm{ppm}$ as a doublet. The 13C NMR spectrum showed two carbonyl peaks at $\delta 172.4(\mathrm{C}=\mathrm{O}$ ester $)$ and $\delta 163.3 \mathrm{ppm}(\mathrm{C}=\mathrm{O}$ amide), $\delta$ 116.1-155.2 ppm (benzilic carbons), $\delta 35.1,58.3$, and $62.6 \mathrm{ppm}$ (methine carbons), $\delta$ 11.1 and 14.4 ppm (methyl carbons), which correlated with the structure of tyrosine-isoleucine (Tyr-Ile) (Table 2). These data strongly suggest that the purified peptide, FII-B(IV)-VII, is a Tyr-Ile dipeptide, which is a novel dipeptide reported for the first time in this work. The molecular weight and isoelectric point (pI) of Tyr-Ile were calculated to be 294.35 Da and 5.9, respectively, using the ChemBioDraw 11 program, corresponding to the LC/MS data (294.16 Da).

Kawasaki et al. (2000) reported that a dipeptide (Val-Tyr) 
Table 2. $1 \mathrm{H}$ and $13 \mathrm{C}$ NMR chemical shifts for the FII-B(IV)-VII

\begin{tabular}{lrr}
\hline Position & 13C NMR & 1H NMR \\
\hline Tyr $\mathbf{1}$ & & \\
$\mathrm{CO}$ & 163.3 & \\
$\mathrm{C} \alpha / \mathrm{H} \alpha$ & 58.3 & 3.97 \\
$\mathrm{C} \beta / \mathrm{H} \beta$ & 35.9 & $2.95,3.08$ \\
$\mathrm{C} 1$ & 126.2 & \\
$\mathrm{C} 2,6 / \mathrm{H} 2,6$ & 130.9 & 7.01 \\
$\mathrm{C} 3,5 / \mathrm{H} 3,5$ & 116.1 & 6.71 \\
$\mathrm{C} 4 / \mathrm{OH}$ & 155.2 & 4.72 \\
Ile 2 & & \\
$\mathrm{COO}$ & 172.4 & \\
$\mathrm{C} \alpha / \mathrm{H} \alpha$ & 62.6 & 3.73 \\
$\mathrm{C} \beta / \mathrm{H} \beta$ & 35.1 & 1.87 \\
$\mathrm{C} \gamma(\mathrm{CH} 3)$ & 14.4 & 0.85 \\
$\mathrm{C} \gamma(\mathrm{CH} 2)$ & 24.8 & $1.14,1.32$ \\
$\mathrm{C} \delta / \mathrm{H} \delta$ & 11.1 & 0.77 \\
\hline
\end{tabular}

The chemical shift $(\delta)$ values were expressed in ppm and were referenced to the residual solvent signals with resonances at $\delta \mathrm{H} / \delta \mathrm{C}, 7.26 / 77.0\left(\mathrm{CDCl}_{3}\right)$.

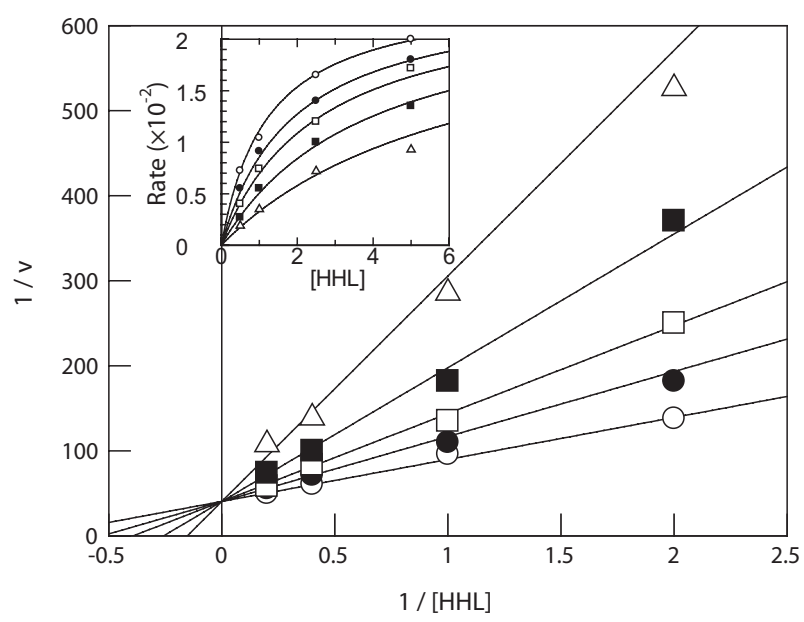

Fig. 5. Lineweaver-Burk plot of FII-B(IV)-VII on ACE reaction. A series of FII-B(IV)-VII $(0,0.5,1.0,2.0,4.0 \mu \mathrm{g} / \mathrm{mL})$ was included in the reaction solution and the $K_{\mathrm{i}}$ was calculated by using the Grafit 5.0 program. $\mathrm{HHL}$, hipuryl-L-histidyl-L-leucine; $\circ, 0 \mu \mathrm{g} / \mathrm{mL} ; \bullet, 0.5 \mu \mathrm{g} / \mathrm{mL} ; \square, 1.0 \mu \mathrm{g} / \mathrm{mL} ; \mathbf{\square}, 2.0$ $\mu \mathrm{g} / \mathrm{mL} ; \Delta, 4.0 \mu \mathrm{g} / \mathrm{mL}$.

purified from sardine muscle hydrolysate had a significant antihypertensive effect on mildly hypertensive subjects via ACE inhibition. Erdmann et al. (2006) reported that sardine muscle hydrolysate contained a Met-Tyr dipeptide that showed ACEinhibitory activity and was capable of diminishing free radical formation in human endothelial cells.

\section{IC 50 value and kinetic analysis}

The ACE inhibition pattern of the purified peptide was investigated by applying a Lineweaver-Burk plot. Tyr-Ile acts as a competitive inhibitor of ACE, suggesting that Tyr-Ile from $N$. nomurai competes with the substrate at the active site of ACE. The $\mathrm{IC}_{50}$ and $K_{\mathrm{i}}$ values of Tyr-Ile were $6.56 \pm 1.12 \mu \mathrm{M}$ $(1.93 \pm 0.33 \mu \mathrm{g} / \mathrm{mL}$ ) and $3.10 \pm 0.28 \mu \mathrm{M}$, respectively (Fig. 5). The inhibition pattern of Tyr-Ile was similar to those of fibrinogen pentapeptides, casein fragments, porcine plasma tripeptides, and tuna muscle octapeptide (Sugiyama et al., 1991; Astawan et al., 1995). Cheung et al. (1980) reported that tryptophan, tyrosine, proline, or phenylalanine at the carboxy-terminal and branched-chain aliphatic amino acids at the amino-terminal are suitable for competitive inhibition of ACE. Fujita and Yoshikawa (1999) reported that LKPNM is a prodrug type of ACE-inhibitory peptide because LKPNM was hydrolyzed by ACE to produce LKP, which exhibited an ACEinhibitory activity eightfold higher than LKPNM. After oral administration in SHR, the antihypertensive effect of LKPNM was maximal after $6 \mathrm{~h}$ and that of LKP at $4 \mathrm{~h}$.

Some antihypertensive drugs are known to produce side effects, such as an abnormal elevation of blood pressure. However, jellyfish is a favorite seafood in Southeast and East Asian nations. Thus, jellyfish may be a useful functional food for maintenance of blood pressure within the normal range. Our results also suggest that an ACE inhibitor derived from N. nomurai can be utilized in the development of physiologically functional foods.

\section{Acknowledgments}

This work was funded by a grant from the National Fisheries Research \& Development Institute (RP-2011-BT-063).

\section{References}

Astawan M, Wahyuni M, Yasuhara T, Yamada K, Tadokoro T and Maekawa A. 1995. Effects of angiotensin-I converting enzyme inhibitory substances derived from Indonesian dried-salted fish on blood pressure of rats. Biosci Biotechnol Biochem 59, 425-429.

Byun HG and Kim SK. 2001. Purification and characterization of angiotensin I converting enzyme (ACE) inhibitory peptides from Alaska pollack (Theragra chalcogramma) skin. Process Biochem $36,1155-1162$.

Cheung HS, Wang FL, Ondetti MA, Sabo EF and Cushman DW. 1980. Binding of peptide substrates and inhibitors of angiotensin converting enzyme. Importance of the $\mathrm{COOH}$-terminal dipeptide sequence. J Biol Chem 255, 401-407.

Cushman DW and Cheung HS. 1971. Spectrophotometeric assay and properties of angiotensin-converting enzyme of rabbit lung. Biochem Pharmacol 20, 1637-1648.

Dziuba J, Minkiewicz P and Nalecz D. 1999. Biologically active peptides from plant and animal proteins. Pol J Food Nutr Sci 8, 3-16.

Erdmann K, Grosser N, Schipporeit K and Schröder H. 2006. The ACE inhibitory dipeptide Met-Tyr diminishes free radical formation in 
human endothelial cells via induction of heme oxygenase-1 and ferritin. J Nutr 136, 2148-2152.

FitzGerald RJ, Murray BA and Walsh DJ. 2004. The emerging role of dairy protein and bioactive peptides in nutrition and health: hypotensive peptides from milk proteins. J Nutr 134, 980S-988S.

Fujita H and Yoshikawa M. 1999. LKPNM: a prodrug-type ACE-inhibitory peptide derived from fish protein. Immunopharmcology 44, 123-127.

Gao D, Chang T, Li H and Cao Y. 2010. Angiotensin I-converting enzyme inhibitor derived from cottonseed protein hydrolysate. Afr J Biotechnol 9, 8977-8983.

Gobbetti M, Ferranti P, Smacchi E, Goffredi F and Addeo F. 2000. Production of angiotensin-I-converting-enzyme-inhibitory peptides in fermented milks started by Lactobacillus delbrueckii subsp. Bulgaricus SS1 and Lactococcus lactis subsp. Cremoris FT4. Appl Environ Microbiol 66, 3898-3904.

He H, Chen X, Sun C, Zhang Y and Gao P. 2006. Preparation and functional evaluation of oligopeptide-enriched hydrolysates from shrimp (Acetes chinesis) treated with crude protease from Bacillus sp. SM98011. Bioresour Technol 97, 385-390.

Jang A and Lee M. 2005. Purification and identification of angiotensin converting enzyme inhibitory peptides from beef hydrolysates. Meat Sci 69, 653-661.

Je JY, Park JY, Jung WK, Park PJ and Kim SK. 2005. Isolation of angiotensin I converting enzyme (ACE) inhibitor from fermented oyster sauce, Crassostrea gigas. Food Chem 90, 809-814.

Kawasaki T, Seki E, Osajima K, Yoshida M, Asada K, Matsui T and Osajima Y. 2000. Antihypertensive effect of valyl-tyrosine, a short chain peptide derived from sardine muscle hydrolyzate, on mild hypertensive subjects. J Hum Hypertens 14, 519-523.

Kim SK, Choi YR, Park PJ, Choi JH and Moon SH. 2000. Screening of biofunctional peptides from cod processing wastes. J Korean Soc Agric Chem Biotechnol 43, 225-227.

Kim TJ, Yoon HD, Lee DS, Jang YS, Suh SB and Yeum DM. 1996. Angiotensin I converting enzyme inhibitory activity of hot-water extract and enzymatic hydrolysate of fresh water fish. J Korean Soc Food Sci Nutr 25, 871-877.

Kohama Y, Matsumoto S, Oka H, Teramoto T, Okabe M and Mimura T. 1988. Isolation of angiotensin-converting enzyme inhibitor from tuna muscle. Biochem Biophys Res Commun 155, 332-337.

Lee HD, Kim KS and Do JR. 2001. Separation and purification of angiotensin-I converting enzyme inhibitory peptides from laver hydrolysate. J Korean Fish Sci 34, 164-172.

Lee KJ, Kim SB, Ryu JS, Shin HS and Lim JW. 2005. Separation and purification of angiotensin converting enzyme inhibitory peptides derived from goat's milk casein hydrolysates. Asian-Aust J Anim Sci 18, 741-746.

Matsui T, Matsufuji H, Seki E, Osajima K, Nakashima M and Osajima Y. 1993. Inhibition of angiotensin I-converting enzyme by Bacillus licheniformis alkaline protease hydrolyzates derived from sardine muscle. Biosci Biotechnol Biochem 57, 922-925.

Miguel M, Alonso MJ, Salaices M, Aleixandre A and López-Fandiňo R. 2007. Antihypertensive, ACE-inhibitory and vasodilator properties of egg white hydrolysates: effect of a simulated intestinal digestion. Food Chem 104, 163-168.

Ondetii MA, Rubin B and Cushman DW. 1977. Design of specific inhibitors of angiotensin-converting enzyme: a new class of orally active antihypertensive agents. Science 196, 441-444.

Shahidi F and Zhong Y. 2008. Bioactive peptides. J AOAC Int 91, 914931.

Smacchi E and Gobbetti M. 1998. Peptides from several Italian cheeses inhibitory to proteolytic enzymes of lactic acid bacteria, Pseudomonas fluorescens ATCC 948 and to the angiotensin I-converting enzyme: design, synthesis, and utilization. Enzyme Microb Technol 22, 687-694.

Sugiyama K, Takada K, Egawa M, Yamamoto I, Onzuka H and Oba K. 1991. Hypotensive effect of fish protein hydrolysate. Nippon Nogeikagaku Kaishi 65, 35-43.

Taylor WH. 1957. Formol titration: an evaluation of its various modifications. Analyst 82, 488-498.

Vermeirssen V, Van Camp J and Verstraete W. 2004. Bioavailability of angiotensin I converting enzyme inhibitory peptides. Br J Nutr 92, 357-366.

Wu H, He AL, Che XL, Sun CY, Zhang YZ and Zhou BC. 2008. Purification and identification of novel angiotensin-I-converting enzyme inhibitory peptides from shark meat hydrolysate. Process Biochem 43, 457-461. 